\title{
Putting Right Holders in the Centre: Bolagsupplysningen and Ilsjan (C-194/16): What Does It Mean for International Jurisdiction over Transborder Intellectual Property Infringement Disputes?
}

\author{
Lydia Lundstedt
}

Published online: 5 November 2018

(C) The Author(s) 2018

\begin{abstract}
This paper analyses what the decision in Bolagsupplysningen and Ilsjan (C194/16) means for international jurisdiction under EU Regulation No 1215/2012 with respect to transborder intellectual property infringement disputes. In this case, the Court of Justice of the European Union extended "the centre of interests" basis of jurisdiction under Art. 7(2) of EU Regulation No 1215/2012 to legal persons claiming infringements of personality rights on the internet. The Court also held that actions for rectification and removal of content infringing personality rights may not be brought before the courts of a Member State where the content is accessible. This article concludes that the centre of interests basis of jurisdiction is generally not applicable to right holders claiming infringements of intellectual property rights and/or complementary tort claims, except arguably for claims for the infringement of moral rights and unfair competition claims where the act exclusively affects the interests of a specific competitor. Many questions remain with respect to the localisation of a victim's centre of interests. In addition, the article concludes that the judgment in Bolagsupplysningen does not affect a right holder's ability to obtain an injunction in the Member State in which content accessible on the internet infringes a forum IP right to put an end to the infringement in that State. Still, the centre of interests basis of jurisdiction has the potential to give right holders an advantage for claims of online infringements of moral rights and acts of unfair competition that exclusively affect them and it can be expected that authors and traders will take advantage of this opportunity when considering their IP litigation strategies.
\end{abstract}

\footnotetext{
L. Lundstedt $(\bowtie)$

Dr.; Senior Lecturer in Intellectual Property Law, Department of Business Law, Institute for Economics and Industrial Development, Linköping University, Linköping, Sweden e-mail: Lydia.lundstedt@juridicum.su.se
}

\section{Lundstedt}

Senior Lecturer in Private International Law, Law Department, Stockholm University, Stockholm, Sweden 
Keywords International jurisdiction - Brussels regulation - Applicable law · Intellectual property $\cdot$ Moral rights $\cdot$ Personality rights $\cdot$ Unfair competition

\section{Introduction}

In Bolagsupplysningen and Ilsjan (C-194/16) ("Bolagsupplysningen"), ${ }^{1}$ the Court of Justice of the European Union ("CJEU") extended "the centre of interests" basis of jurisdiction under Art. 7(2) of EU Regulation No 1215/2012 ("Brussels Ia Regulation" or "BIa") ${ }^{2}$ to legal persons claiming infringements of personality rights on the internet. ${ }^{3}$ The centre of interests basis of jurisdiction allows the victim to bring an action in the Member State where he/she is "at home" in contrast to the general rule that a defendant must be sued in the Member State of the defendant's domicile. The CJEU created this basis of jurisdiction in its earlier judgment, eDate Advertising and others (C-509/09 and C-161/10) ("eDate"), ${ }^{4}$ by localising the damage under Art. 7(2) BIa to the place of the victim's centre of interests. ${ }^{5}$ As the victims in $e$ Date were natural persons, the judgment left open the question whether the centre of interests basis of jurisdiction could be invoked by legal persons claiming infringements of personality rights on the internet. In Bolagsupplysningen, the CJEU answers this question in the affirmative.

In Bolagsupplysningen, the CJEU also held that actions for rectification and removal of content infringing personality rights may not be brought before the courts of a Member State where damage allegedly occurs based on the accessibility of the content in that Member State. ${ }^{6}$ In eDate, the CJEU had held that notwithstanding the centre of interests basis of jurisdiction, the victim of personality infringements over the internet still had the option to bring his/her action before the courts of each Member State in whose territory content placed online is or has been accessible ("the mosaic approach"). ${ }^{7}$ Consistent with established CJEU practice, the CJEU held that those courts have jurisdiction only in respect of the damage caused in the territory of the Member State of the court seised. ${ }^{8}$ The CJEU did not, however, specifically address the scope of the Member State courts' jurisdiction

\footnotetext{
${ }^{1}$ See judgment of 17 October 2017, Bolagsupplysningen and Ilsjan (C-194/16) ECLI:EU:C:2017:766 ("Bolagsupplysningen").

2 Regulation (EU) No 1215/2012 of the European Parliament and of the Council of 12 December 2012 on jurisdiction and the recognition and enforcement of judgments in civil and commercial matters (Brussels Ia Regulation or "BIa").

3 See Bolagsupplysningen, point 1 of the operative part of the judgment.

4 Judgment of 25 October 2011, eDate Advertising and others (C-509/09 and C-161/10, ECR 2011 p. I-10269) ECLI:EU:C:2011:685 (“eDate”).

5 See eDate, para. 48 ("The connecting criteria referred to in paragraph 42 of the present judgment must therefore be adapted in such a way that a person who has suffered an infringement of a personality right by means of the internet may bring an action in one forum in respect of all of the damage caused, depending on the place in which the damage caused in the European Union by that infringement occurred.”). But see Lutzi (2017), pp. 695-696.

6 Bolagsupplysningen, para. 49.

7 eDate, paras. 51-52.

8 eDate, paras. 51-52.
} 
with respect to specific remedies. ${ }^{9}$ Bolagsupplysningen makes clear that these courts do not have jurisdiction to order removal and/or rectification of the content with effect for all Member States.

While the holdings in Bolagsupplysningen were limited to infringements of personality rights over the internet, the CJEU's reasoning may have relevance for infringements of other rights over the internet. ${ }^{10}$ With respect to the centre of interests basis of jurisdiction, however, the CJEU has previously held that it is not applicable to damage arising from the infringement of registered trademarks and economic rights conferred by copyright. ${ }^{11}$ The reason for this is that unlike personality rights, registered trademarks and economic rights conferred by copyright are territorially limited to the Member State of registration and protection. This leaves open the question whether right holders may invoke the centre of interests basis of jurisdiction for infringements of other types of intellectual property (IP) rights, in particular those rights where the principle of territoriality is not as firmly established, and for complementary tort claims that may be brought instead of or in addition to infringement actions.

The question is also raised whether Bolagsupplysningen eliminates the jurisdiction of the courts of each Member State where an IP right is registered and/or protected and alleged infringed due to its accessibility in the that Member State, to grant an injunction to stop the infringement there. Injunctions are the most commonly sought remedy in IP infringement disputes and are usually sought in the state of registration or protection of the IP right alleged infringed. ${ }^{12}$

The aim of this article is to analyse what Bolagsupplysningen means for international jurisdiction under the Brussels Ia Regulation for transborder IP infringement disputes. First, the article presents and analyses the Bolagsupplysningen judgment. Second, it analyses to what extent the centre of interests basis of jurisdiction is available to right holders claiming infringements of IP rights and/or complementary tort claims that may be brought instead of or in addition to infringement actions. Next, it analyses whether the courts of a Member State where an IP right is registered and/or protected and alleged infringed due to the accessibility of infringing content in that Member State, have jurisdiction to grant an injunction to stop the infringement in that Member State. Lastly, the article prognosticates with respect to the effect of Bolagsupplysningen for IP strategies in transborder disputes.

\footnotetext{
${ }^{9}$ Even though the referring court had asked about jurisdiction to grant an injunction, the CJEU's answer deals only with an action for liability for damage. See eDate, para. 24 and operative part of the judgment point 1.

${ }^{10}$ Bogdan (2017-2018), p. 677; Zingales (2017), p. 31.

11 Judgment of 19 April 2012, Wintersteiger (C-523/10, Publié au Recueil numérique) ECLI:EU:C:2012:220 ("Wintersteiger"), paras. 24-25 (trademark); judgment of 3 October 2013, Pinckney (C-170/12) ECLI:EU:C:2013:635 ("Pinckney"), para. 46 (copyright). In Pinckney, the CJEU was not as explicit in rejecting the centre of interests basis of jurisdiction as it was in Wintersteiger; it follows, however, from the CJEU's reasoning. See Pinckney paras. 36-47.

12 Christie (2017), p. 168.
} 


\section{Bolagsupplysningen and Ilsjan (C-194/16)}

In Bolagsupplysningen, a company incorporated under Estonian law with its main business activities in Sweden (Bolagsupplysningen) and an employee of that company (Ms Ilsjan) brought an action in Estonia against a Swedish trade association (Svensk Handel) for the infringement of personality rights. The dispute arose because Svensk Handel had "blacklisted" Bolagsupplysningen on its website, alleging that the company carried out billing fraud. This "blacklisting" attracted over 1000 negative comments on the discussion forum on Svensk Handel's website, and some comments called for acts of violence against Bolagsupplysningen and Ms Ilsjan. Svensk Handel refused to remove Bolagsupplysningen from the blacklist and refused to delete the comments.

The case reached the Estonian Supreme Court, which referred three questions to the CJEU concerning the extent of the Estonian courts' jurisdiction under Art. 7(2) of the Brussels Ia Regulation with respect to the dispute between Bolagsupplysningen and Svensk Handel. Essentially, the Estonian court asked (1a) whether the centre of interests basis of jurisdiction extended to legal persons, and if so, (1b) what criteria and circumstances should be taken into account to determine that centre of interests; and (2) whether a victim of personality rights infringement on the internet can bring an action for rectification and/or removal of content in the Member State where the content is or has been accessible.

\subsection{Centre of Interests Basis of Jurisdiction}

In Bolagsupplysningen, the CJEU held that the centre of interests basis of jurisdiction applied to legal persons claiming infringements of personality rights on the internet. The centre of interests basis of jurisdiction is a derivative of Art. 7(2) BIa, which is a rule of special jurisdiction that derogates from the general rule that a defendant who is domiciled in a Member State shall be sued in the courts of that Member State. ${ }^{13}$ Article 7(2) BIa stipulates that for matters relating to tort, delict or quasi-delict, the defendant may be sued in the courts for the place where the harmful event occurred or may occur. Pursuant to established CJEU case law, this concept includes the place of the event giving rise to the damage and the place where the damage occurs. ${ }^{14}$ With respect to the infringement of personality rights through printed media, the CJEU has held that the damage occurs in every Member State where the content is distributed, when the victim is known in those places, but that these courts have jurisdiction only with respect to damage occurring within their territories. ${ }^{15}$

In its earlier judgment in eDate, the CJEU localised the damage occurring from personality infringements over the internet to the place of the victim's centre of interests. ${ }^{16}$ This was because the CJEU had found that the distribution criterion was

\footnotetext{
13 See Art. 4 BIa.

14 See e.g., judgment of 7 March 1995, Shevill and others/Presse Alliance, ECLI:EU:C:1995:61 ("Shevill"); 21/76, judgment of 30 November 1976, Handelskwekerij Bier/Mines de Potasse d'Alsace, ECLI:EU:C:1976:166.

15 See Shevill, paras. 29-30.

16 eDate, para. 48.
} 
not useful with respect to distribution by internet due to its ubiquity. ${ }^{17}$ The CJEU also suggested that the distribution criterion was unfair to the victim due to the serious nature of the harm suffered by the victim from the worldwide distribution. ${ }^{18}$ The CJEU therefore adapted the damage head of jurisdiction by localising the damage at the victim's centre of interests because the courts in that Member State were best placed to assess the impact that the material placed online has on the victim's personality rights. ${ }^{19}$ According to the CJEU, a victim's centre of interests was situated in the Member State of the victim's habitual residence, although it noted, "a person may also have the centre of his interests in a Member State in which he does not habitually reside, in so far as other factors, such as the pursuit of a professional activity, may establish the existence of a particularly close link with that State." ${ }^{20}$ In addition, the CJEU observed that the criterion of the centre of interests accords with the Brussel Ia Regulation's aim of predictability as it allows the victim to identify the court in which he/she may sue, and the defendant to reasonably foresee before which court he/she may be sued. ${ }^{21}$ The reason is that the defendant publishing content that allegedly infringes personality rights is in a position to know the centre of interests of the person who is the subject of that content, and that person is likely to be able to identify his/her own centre of interests. ${ }^{22}$

In Bolagsupplysningen, the CJEU found that the reasoning in eDate was equally applicable to legal persons claiming an infringement of personality rights on the internet. The CJEU explained that the question whether the damage was material or non-material had no bearing on jurisdiction, regardless of the fact that it might be treated differently under the applicable substantive law. ${ }^{23}$ In addition, the CJEU noted that the objective of the basis for jurisdiction under Art. 7(2) BIa was not to protect the weaker party but to facilitate the sound administration of justice. ${ }^{24}$

With respect to the localisation of a legal person's centre of interests, the CJEU held that it must reflect the place where the legal person's commercial reputation is most firmly established, which is determined by reference to the place where it carries out the main part of its economic activities. ${ }^{25}$ According to the CJEU, this place does not necessarily need to coincide with the legal person's registered office, such as the situation in the dispute in the main proceedings. This is because the legal person's commercial reputation which is likely to be affected by the publication is greater in the Member State where it carries out the main part of its economic activities and, therefore, any injury to that reputation would be felt most keenly there. ${ }^{26}$ The CJEU explained that the courts of that Member State were best placed to assess the existence and scope of the alleged injury, in particular because the

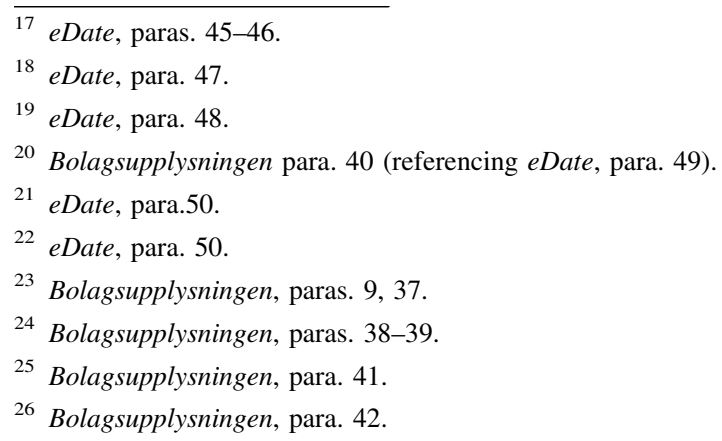


cause of the injury was content published "on a professional site managed in the Member State in which the relevant legal person carries out the main part of its activities and that are, bearing in mind the language in which they are written, intended, for the most part, to be understood by people living in that Member State." 27 Finally, the CJEU added that if it was not clear at the stage when a court assesses its jurisdiction that the economic activity of the relevant legal person is carried out mainly in a certain Member State, so that its centre of interests cannot be identified, that person cannot invoke the centre of interests basis of jurisdiction. ${ }^{28}$

The CJEU's rulings in Bolagsupplysningen and in eDate are remarkable in that they lead to a forum actoris rule, which goes against the general rule on the defendant's domicile. This can lead to disturbing results if one envisages a situation where a corporate commercial actor hauls a natural person that allegedly infringes its personality rights before the courts of its own "home" Member State such as a cyber transborder version of the Mclibel case. ${ }^{29}$ Understandably, the CJEU has set a high bar for invoking the centre of interest basis of jurisdiction in that a legal person's centre of interests must be clearly identifiable at the stage that the court assesses its jurisdiction. ${ }^{30}$ There does not seem to be any reason why a high bar should not also apply to natural persons.

The rulings leave many questions unanswered with respect to the localisation of both legal and natural persons' centres of interests. While it is not clear exactly what the CJEU means by "mainly in a certain Member State", it does suggest that legal (and natural) persons that carry out economic activities in several Member States would not have a centre of interests in any one Member State. ${ }^{31}$ At the same time, the CJEU's decisions suggest that the localisation of the victim's centre of interests is dependent upon the circumstances of the actual dispute. For instance, the localisation of the victim's centre of interests in the Member State of his/her habitual residence or in the Member State where he/she pursues professional activities would seem to depend on whether the illegal content affects the person's private or professional sphere, which would depend on various factors concerning the type of injury, the defendant's activities and the content. ${ }^{32}$ In Bolagsupplysningen, the CJEU also suggested that the

\footnotetext{
27 Bolagsupplysningen, para. 42.

28 Bolagsupplysningen, para. 43.

29 See McDonald's Corporation v. Steel \& Morris [1997] EWHC QB 366 where McDonalds sued two environmental activists for defamation following the publication and distribution of a critical leaflet. The case reached the European Court of Human Rights that held that the United Kingdom violated the principle of equality of arms by denying the activists legal aid (violation of Art. 6\$1) and failed to strike the correct balance between the need to protect the applicants' right to freedom of expression and the need to protect the rights and reputation of the plaintiff companies (violation of Art. 10). See Steel and Morris against the United Kingdom, Application No. 68416/01, judgment of 15 February 2005, final on 15 May 2005.

30 Bolagsupplysningen, para. 43. See also Lutzi (2018), p. 210.

31 See Lutzi (2018), p. 210 (submitting that the CJEU appears to have created a high threshold for invoking the centre of interests basis of jurisdiction). See also Bogdan (2017-2018), p. 677 (stating that an example where a legal person's centre of interests in a Member State cannot be identified would be when the legal person has its centre of interests outside of the EU).

32 See Bogdan (2017-2018), p. 676. See also Opinion of Advocate General Cruz Villalón, eDate, paras. 59-66 (advocating in favour of jurisdiction based on the centre of gravity, composed of two elements,
} 
circumstances of the actual dispute may play a role when it observed that the allegedly infringing content was published on a website managed in the Member State where the injured legal person carries out the main part of its activities and in a language understood by people living there. ${ }^{33}$

\subsection{Jurisdiction over Actions for Rectification and Removal}

In Bolagsupplysningen, the CJEU also ruled that the courts of each Member State where content allegedly infringing personality rights is or has been accessible within its territory do not have jurisdiction to order rectification and/or removal of content when exercising jurisdiction under Art. 7(2) BIa on the basis of damage within its territory. The CJEU acknowledged its holding in eDate where it ruled that a person who considers that his/her personality rights have been infringed may bring an action for damages before the courts of each Member State in whose territory content placed online is or has been accessible, which have jurisdiction only in respect of the harm caused in the territory of the Member State of the court seised. The CJEU distinguished, however, an application for rectification and/or removal from an action for damages because in light of the "single and indivisible" nature of an application for rectification/removal, the remedy would have effect in the territory of other Member States outside of the jurisdiction of the forum Member State. Consequently, the CJEU held that "in light of the ubiquitous nature of the information and content placed online on a website and the fact that the scope of their distribution is, in principle, universal" an application for rectification and/or removal may be made only before a court with jurisdiction to rule on the entirety of an application for compensation for damage. ${ }^{34}$

\section{Centre of Interests and Intellectual Property Rights and Complementary Tort Claims}

The question raised here is what Bolagsupplysningen (and eDate) means for the possibility for a right holder to bring an infringement claim or complementary tort claim that may be brought instead of or in addition to infringement claims at the right holder's centre of interests. Indeed, the extension of the centre of interests basis of jurisdiction to legal persons gives it a broader scope of application that is likely to be exploited, where possible, by right holders who are often legal persons.

This section first analyses how the CJEU distinguished infringements of registered trademarks and economic rights conferred by copyright from

\footnotetext{
Footnote 32 continued

namely, the victim's centre of interests and the nature of the information communicated in the dispute at hand, i.e. whether it is objectively relevant to the particular territorial area).

33 See also Lutzi (2018), p. 210 (stating that the decision in Bolagsupplysningen confirms that the centre of interest criterion relies on a presumption that a plaintiff's centre of interests is localised at his/her habitual residence or the legal persons' registered office, but this can be rebutted by showing that they carry out the main part of their economic activities in a different Member State).

34 Bolagsupplysningen, para. 48.
} 
infringements of personality rights. Second, it analyses whether this reasoning is applicable to well-known and unregistered trademarks, moral rights conferred by copyright, and complementary torts claims that may be brought instead of or in addition to infringement actions.

\subsection{Registered Trademarks and Economic Rights Conferred by Copyright}

The CJEU has previously held that the centre of interests basis of jurisdiction is not applicable to damage occurring from the infringement of registered trademarks and economic rights conferred by copyright. ${ }^{35}$ According to the CJEU, the place where the damage occurs may vary according to the nature of the right allegedly infringed, and the likelihood of damage occurring in a particular Member State is subject to the condition that the right whose infringement is alleged is protected in that Member State. ${ }^{36}$ Consequently, the CJEU held that damage occurs (only) where the trademark is registered or where the economic rights conferred by copyright are subject to protection and capable of being infringed. ${ }^{37}$

The reason is that in contrast to personality rights, which protect a person everywhere, the protection afforded by registered trademarks and economic rights conferred by copyright is territorially limited to the Member State of registration and/or protection. ${ }^{38}$ The CJEU found that this was true also for the economic rights conferred by copyright notwithstanding that these rights, similarly to personality rights, are automatically protected in all Member States because the protection conferred by each Member State is territorially limited. ${ }^{39}$ Consequently, the Member State where the right holder has its centre of interests is not appropriate to decide the dispute with a view to the ease of taking up evidence, because the relevant evidence to prove the existence and extent of the infringement is located in each and every Member State where the right is registered and/or protected and not concentrated in any one Member State. Conferring jurisdiction on the courts of a single Member State of the right holder's centre of interests would therefore not correspond to the objective of the sound administration of justice. ${ }^{40}$

Moreover, it seems that the CJEU was aware that pursuant to Art. 8 EU Regulation 864/2007 ("Rome II"), ${ }^{41}$ the law applicable to ubiquitous infringements of registered trademarks and economic rights conferred by copyright is the laws of

\footnotetext{
35 Wintersteiger, paras. 24-25 (trademark); Pinckney, para. 46 (copyright). As noted, the CJEU was not as explicit in the case of copyright but it follows from its reasoning.

36 Pinckney, paras. 31-32; judgment of 21 December 2016, Concurrence (C-618/15) ECLI:EU:C:2016:976 ("Concurrence"), para. 30.

37 Wintersteiger, para. 29 (trademark); Pinckney, para. 43 (copyright); judgment of 22 January 2015, Hejduk (C-441/13) ECLI:EU:C:2015:28 (“Hejduk"), para. 29 (copyright).

38 Wintersteiger, paras. 24-25 (trademark); Pinckney, para. 46 (copyright); Hejduk, para. 22 (copyright).

39 Pinckney, para. 39.

40 Relevant evidence may also be found in the Member State where the event giving rise to the damage occurred, which justifies the attribution of jurisdiction to this Member State. See Wintersteiger, paras. 32-39.

41 Regulation (EC) 864/2007 of the European Parliament and of the Council of 11 July 2007 on the law applicable to non-contractual obligations ("Rome II").
} 
the countries for which protection is claimed on a distributive country-by-country basis. ${ }^{42}$ Thus, if jurisdiction would be conferred on the courts of the Member State of the right holder's centre of interests, the adjudicating court would have to apply multiple laws. ${ }^{43}$

In contrast, when it comes to infringements of personality rights, a Member State court at the victim's centre of interests will often be able to assess all the damage under its own law. ${ }^{44}$ Rome II excludes personality rights from its material scope of application, so the adjudicating Member State court would need to apply its own conflict rules. ${ }^{45}$ Even though the conflict of law rules of the Member States with respect to personality rights infringements are widely divergent, a common denominator is that they often lead to the application of a single law as opposed to a distributive application of the laws where the content was distributed or accessible. ${ }^{46}$ Moreover, the rules are such that the Member States can often end up applying their own law. ${ }^{47}$

Consequently, the courts of a Member State where a trademark is registered or which protect economic rights conferred by copyright, are not best placed to assess the infringement of trademarks and economic rights conferred by copyright taking place in other Member States and infringing other Member States' laws. Indeed, if the court also had jurisdiction to adjudicate on the damage arising from the infringements of trademarks and economic rights conferred by copyright in other Member States, it would substitute itself for these Member States' courts, which are best placed to rule on the damage within their own territories and under their own laws. $^{48}$

With respect to registered trademarks, the CJEU observed that the objective of foreseeability is best served if a dispute concerning the infringement of a registered trademark is brought in the Member State where the trademark at issue is registered. ${ }^{49}$ While the CJEU does not explicitly state this, it seems logical to

\footnotetext{
42 See Wintersteiger, para. 26; Fawcett and Torremans (2011), p. 818.

43 See judgment of 5 July 2018, flyLAL-Lithuanian Airlines (C-27/17) ECLI:EU:C:2018:533 (" $f l y L A L$ Lithuanian Airlines"), para. 41 (discussing the requirement for consistency between the rules of jurisdiction and applicable law); Concurrence, para. 32 (finding a natural link between the forum Member State and the dispute because the infringement of a prohibition on resale outside of a selective distribution network was governed by forum law).
}

44 Pursuant to Directive 2000/31/EC on certain legal aspects of information society services, in particular electronic commerce, in the Internal Market ("Directive on electronic commerce"), however, a provider of an electronic commerce service may not be subject to stricter requirements than those provided for by the substantive law applicable in the Member State in which that service provider is established. eDate, para. 68 .

45 Art. 1(2)(g) Rome II (excluding "non-contractual obligations arising out of violations of privacy and rights relating to personality, including defamation").

46 See generally Comparative study (2009), pp. 79-112.

47 See generally Comparative study (2009), p. 141. See also Svantesson (2016), p. 30 (remarking that states tend to be more protective in the field of defamation law than other fields because freedom of expression and protection of reputation go to the very core of a society).

48 See Pinckney, para. 46.

49 Wintersteiger, para. 27. 
assume that defendants can easily search databases for possible trademark registrations. It is perhaps not surprising that the CJEU did not rely on the objective of foreseeability to justify allowing right holders to bring an infringement claim in every Member State where the economic rights conferred by copyright are subject to protection and capable of being infringed as this means a potential defendant can be sued in any Member State. ${ }^{50}$

As the CJEU localised the damage that occurs from the infringement of a registered trademark under Art. 7(2) BIa in the Member State of registration, issues concerning the exclusive jurisdiction of the Member State's courts under Art. 24(4) BIa over proceedings concerned with the registration or validity of patents, trademarks, designs and other rights registered in their territories will not arise. ${ }^{51}$ Indeed, the courts of the Member State having jurisdiction under the damage head of Art. 7(2) BIa are the courts of the Member State having exclusive jurisdiction over validity and registration proceedings under Art. 24(4) BIa. This may be another (implicit) reason why the CJEU localised the damage in the Member State of registration. It is submitted that the CJEU's reasoning with respect to registered trademarks and economic rights conferred by copyright is equally applicable to other national registered IP rights (i.e. patents and registered designs) as these are characterised by the principle of territoriality. ${ }^{52}$ It is not as clear, however, whether the centre of interests basis of jurisdiction might be invoked for other IP rights or complementary tort claims.

\subsection{Well-Known and Unregistered Trademarks}

The CJEU has not ruled on the applicability of the centre of interests basis of jurisdiction to well-known and unregistered trademarks. There does not seem to be any reason why these rights should be treated any differently from registered trademarks and economic rights conferred by copyright. ${ }^{53}$ That is, for the purpose of attributing jurisdiction, damage arises (only) in a Member State where a well-known trademark or unregistered trademark is subject to protection and capable of being infringed. ${ }^{54}$ The reason for this is that these rights like other commercial IP rights are characterised by the principle of territoriality, notwithstanding the fact that they are not registered rights.

Pursuant to Art. $6^{\text {bis }}$ of the Paris Convention, all Member States must protect foreign well-known trademarks even when the marks have not been used or

\footnotetext{
50 See Pinckney; Hejduk.

51 See judgment of 13 July 2006, GAT (C-4/03, ECR 2006 p. I-6509) ECLI:EU:C:2006:457 (“GAT") (holding that the rule on exclusive jurisdiction applies to "all proceedings relating to the registration or validity of a patent, irrespective of whether the issue is raised by way of an action or a plea in objection.").

52 Stone (2013), p. 23. See also Schack (2009), p. 158 (stating that registered IP rights are from the start limited to the territory of the granting state).

53 See Wintersteiger, para. 29 (trademark); Pinckney, para. 43 (copyright); Hejduk), para. 29 (copyright).

54 See also C-360/12, judgment of 5 June 2014, Coty Germany, ECLI:EU:C:2014:1318 ("Coty Germany"), para. 55 .
} 
registered in their territories. ${ }^{55}$ In this respect, well-known trademarks are similar to personality rights in that they must be protected in all Member States. A prerequisite for protection, however, is that the mark has obtained some degree of recognition in the protecting Member State. ${ }^{56}$ In this respect they differ from personality rights because the possibility of protection in each Member State depends on whether the mark qualifies as well known in that State. Not every trademark that qualifies as well known in one Member State will qualify for protection as well known in another Member State. Moreover, if a Member State protects a foreign well-known trademark by prohibiting the use of another mark, the prohibition is limited to the territory of that Member State. ${ }^{57}$ The protection granted to a well-known trademark in its country of origin is also limited to the territory of the country of registration (well-known trademarks are usually registered in their countries of origin). ${ }^{58}$

Not all Member States protect unregistered trademarks (beyond what is required under Art. $6^{\text {bis }}$ Paris Convention). ${ }^{59}$ Those Member States that do protect unregistered trademarks require that the unregistered trademark has been used or has acquired recognition in that Member State. ${ }^{60}$ In addition, the rights conferred by unregistered trademarks are the same as the rights conferred by registered trademarks, and are limited to the territory of the Member State that protects the right. ${ }^{61}$ Consequently, evidence concerning the extent of an online infringement of a

\footnotetext{
55 See Art. 6 ${ }^{\text {bis }}$ Paris Convention for the Protection of Industrial Property, 20 March 1883 ("Paris Convention". See also Art. 16.2-3 TRIPS (extending the protection to services and to goods or services which are not similar to those in respect of which a trademark is registered).

56 See Art. $6^{\text {bis }}$ Paris Convention ("The countries of the Union undertake, ex officio if their legislation so permits, or at the request of an interested party, to refuse or to cancel the registration, and to prohibit the use, of a trade-mark which constitutes a reproduction, an imitation, or a translation, liable to create confusion, of a mark considered by the competent authority of the country of registration or use to be well known in that country as being already the mark of a person entitled to the benefits of this Convention and used for identical or similar goods. These provisions shall also apply when the essential part of the mark constitutes a reproduction of any such well-known mark or an imitation liable to create confusion therewith.") (emphasis added). See also Peukert (2016), pp. 81-83. Evidence of global registrations and use in other states can be used as evidence, however, to demonstrate that a mark is well known and therefore protected in a Member State. See Art. 2(b)(2-6) WIPO, Joint Recommendation Concerning Provisions on the Protection of Well-Known Marks (2000); Kur (2000), p. 282 (discussing the significance of international recognition for establishing protection in the country of protection in order to prevent appropriation of attractive and valuable marks).

57 See WIPO, Joint Recommendation Concerning Provisions on the Protection of Well-Known Marks 2000, explanatory note 2.8 ("Due to the principle of territoriality, well-known marks are enforced on a national basis.").

58 The extended protection granted to well-known marks with regard to goods or services which are not similar to the goods or services for which the mark is well known is only applicable to well-known marks that are registered in their countries of origin. See Art. 16.3 TRIPS.

59 Von Bomhard and Geier (2017), p. 687.

60 Von Bomhard and Geier (2017), pp. 687-691.

61 Von Bomhard and Geier (2017), pp. 687-691, p. 698. See e.g., Swedish Trademarks Act (2010:1877) Chapter 1, Secs. 7, 10 (giving unregistered trademarks the same protection as registered trademarks). See also Schack (2009), p. 141 (submitting that the rights conferred under unregistered marks are territorially limited just like registered trademarks); judgment of 29 March 2011, Anheuser-Busch/Budějovický Budvar (C-96/09 P, ECR 2011 p. I-2131) ECLI:EU:C:2011:189, para. 162 ("It is in fact only in the territory in which the sign is protected, whether the whole or only part of it is concerned, that the
} 
well-known trademark or an unregistered trademark in one Member State is not relevant to establishing the infringement of the mark in another Member State.

In addition, if the right holder seeks protection for a ubiquitous infringement of a well-known or unregistered trademark, the applicable law will be the laws of all the countries for which protection is claimed on a distributive country-by-country basis. ${ }^{62}$ The Rome II Regulation specifically includes industrial property rights within the scope of its definition, which encompasses unregistered trademarks. ${ }^{63}$ Thus, unregistered trademarks are treated just like registered trademarks for the purpose of the applicable law. Therefore, for the same reasons as with respect to registered trademarks, conferring jurisdiction on the courts of the Member State of the right holder's centre of interests would not correspond to the objective of the sound administration of justice.

With respect to the objective of foreseeability, economic operators cannot easily search for unregistered trademarks in databases as they can do with registered rights. EU law recognises, however, the existence of unregistered trademarks, so an economic operator can be assumed to be aware of the possibility of their existence. ${ }^{64}$ Well-known marks are capable of protection in every Member State, and like copyright, may result in jurisdiction in every Member State in which the use of the mark is accessible. While this is difficult to reconcile with the objective of foreseeability, it has not, however, led the CJEU to abandon the mosaic approach for the economic rights conferred by copyright or even for personality rights. ${ }^{65}$

\subsection{Moral Rights Conferred by Copyright}

The CJEU has not ruled on the applicability of the centre of interests basis of jurisdiction regarding claims for the infringement of moral rights conferred by copyright. In a Swedish case concerning copyright infringement over the internet, the Swedish Supreme Court held that it had jurisdiction under the damage head of Art. 5(3) Lugano Convention (which is basically identical to Art. 7(2) BIa) for all damage to the author's moral rights because the author had his centre of interests in Sweden. ${ }^{66}$ Emphasising the similarity between actions for compensation for the violation of personality rights and actions for the infringement of moral rights under Swedish law,

\section{Footnote 61 continued}

applicable law confers on the sign exclusive rights which may enter into conflict with a Community trade mark."). In some respects, the protection granted to unregistered rights is less than the protection granted to registered rights, but it is hardly greater.

62 See Art. 8(1) Rome II. See also Fawcett and Torremans (2011), p. 818.

63 See recital 26 Rome II Regulation. A starting point for a definition of industrial property rights can be found in the Paris Convention, which includes the protection of unregistered trademarks when they are well known. See Art. $6^{\text {bis }}$ Paris Convention.

64 See Art. 8(4) Regulation (EU) 2017/1001 of the European Parliament and of the Council of 14 June 2017 on the European Union trade mark (the existence of an unregistered trademark is a relative ground for invalidity of a EU trademark).

65 See Heduk, para. 37; Bolagsupplysningen, para. 47.

66 Swedish Supreme Court, NJA 2012, p. 483. 
the Court stated that the reasons underlying the CJEU's judgment in eDate and others were equally relevant in the case of moral rights. ${ }^{67}$

The CJEU has rejected the contention, however, that the applicable substantive law on non-contractual civil liability can be used to interpret the rule on jurisdiction in Art. 7(2). ${ }^{68}$ The rules on jurisdiction in the Brussels Ia Regulation are based on considerations relating to the sound administration of justice and the efficacious conduct of proceedings whereas the applicable substantive law is based on political, economic, and moral considerations concerning the balance of conflicting interests. Consequently, the definitions of legal concepts such as moral rights and the localisation of damage under EU private international law are not always consistent with the definitions of concepts and localisation of damage under the applicable national substantive law. ${ }^{69}$

When determining whether moral rights should be treated like personality rights or like IP rights for the purpose of jurisdiction, it would be interesting to see how they have been treated under EU choice of law rules. ${ }^{70}$ Unfortunately, the Rome II Regulation is not very helpful. It defines IP rights to include copyright and industrial property rights but does not specifically mention moral rights. On the other hand, the exclusion from the Rome II Regulation refers to "Privacy and rights relating to personality, including defamation" but does not explicitly mention moral rights. ${ }^{71}$ While it is outside the scope of this article to conduct a full investigation into the characterisation of moral rights under European private international law, it is fair to say that moral rights bear a close relationship to personality rights. ${ }^{72}$ Indeed, the object of protection for both personality rights and moral rights is the person, as

\footnotetext{
67 Swedish Supreme Court NJA 2012 p. 483 (observing that moral rights protected under Secs. 3 and 54 of the Swedish Copyright Act were closely connected to the author and aimed to protect the author from violations to her artistic reputation and were in that respect similar to personality rights).

68 Judgment of 16 May 2013, Melzer (C-228/11) ECLI:EU:C:2013:305 paras. 34-35; judgment of 19 September 1995, Marinari/Lloyd's Bank (C-364/93, ECR 1995 p. I-2719) ECLI:EU:C:1995:289, paras. $18-19$.

69 See Opinion of Advocate General Jääskinen, delivered on 21 November 2013, Coty Germany, para. 58. See also Rättzén (2017), pp. 335-343 (discussing however that for reasons for procedural economy, it does not make sense to attribute jurisdiction to a Member State if damage is not capable of occurring in that State under the applicable substantive law). The national courts still apply, however, their own procedural law and the substantive law determined by the conflict of law rules to assess the conditions for admissibility. See Shevill, paras. 38-39 ("[The Brussels Convention] does not, however, specify the circumstances in which the event giving rise to the harm may be considered to be harmful to the victim, or the evidence which the plaintiff must adduce before the court seised to enable it to rule on the merits of the case. Those questions must therefore be settled solely by the national court seised, applying the substantive law determined by its national conflict of laws rules, provided that the effectiveness of the Convention is not thereby impaired."). Chalmers et al. (2014), pp. 179-183 (explaining that the CJEU interprets legal concepts in EU regulations and directives autonomously with a view to a uniform application throughout the European Union).

70 Some claims for the infringement of moral rights could be characterised as unfair competition under an autonomous EU definition, such as when a competitor disparages an author's work. See infra discussion under Sect. 3.4.

71 Art. 1(2)(g) Rome II Regulation.

72 See e.g., van Eechoud (2003), p. 139; Davies and Garnett (2016), pp. 16-21; Adeney (2006), pp. 25-29; Platt (2010), p. 955; Hansmann and Santilli (1997), p. 102; Dworkin (1994), p. 229.
} 
opposed to the property itself as is the case with economic rights conferred by IP rights. $^{73}$

If we return to the reasons why the CJEU attributed jurisdiction to the Member State where the victim of personality rights has his/her centre of interests, it appears that these reasons support characterising moral rights as personality rights and localising the damage occurring from the infringement of moral rights to an author's centre of interests. ${ }^{74}$ First, like personality rights, all the Member States protect moral rights in accordance with Art. $6^{\text {bis }}$ of the Berne Convention, so these rights may be infringed in each Member State in accordance with the applicable substantive law. The evidence relevant to proving the impact that material placed online is liable to have on an author's moral rights will usually be concentrated at the place where the author has his/her centre of interests. ${ }^{75}$ This is especially the case when the use or an alteration of the work is alleged to be prejudicial to the author's honour because the author's own subjective view is likely to be relevant to proving the existence of an infringement and/or the extent of the damage. ${ }^{76}$

Second, a Member State court at the author's centre of interests may be able to assess all the damage under one single law and in many cases the court will apply its own law. ${ }^{77}$ This is the case regardless of whether infringements of moral rights are characterised as copyright or as personality rights under EU private international law for the purpose of the applicable law. ${ }^{78}$ If moral rights infringements are characterised as personality rights, as discussed above, the national choice of laws

\footnotetext{
73 A starting point for a definition of personality rights under EU law is chapter 1 of the Charter of Fundamental Rights of the European Union ("EU Charter") which protects the dignity and integrity of the person, Arts. 7 and 8 of the EU Charter on respect for private and family life and protection of personal data, and Art. 8 of the European Convention of Human Rights on right to respect for private and family life. Inspiration can also be drawn from the various laws of the Member States on personality rights even though a EU definition must be formally independent from the national laws. A basic minimum of moral rights protection can be found in Art. $6^{\text {bis }}$ Berne Convention for the Protection of Literary and Artistic Works, 9 September 1886 ("Berne Convention") to which all Member States are contracting parties. The Berne Convention requires the contracting states to ensure that an author has the right to claim authorship of his/her works and to object to any distortion, mutilation or other modification of, or other derogatory action in relation to, the said work, which would be prejudicial to his honour or reputation.

74 Xalabarder (2015), pp. 176-177; Bogdan (2013), p. 200; Maunsbach (2012), pp. 58-59.

75 Maunsbach (2012), pp. 58-59 (stating that in the majority of cases, the integrity of the work will be most significantly affected in the country where the right holder has his/her habitual residence).

76 See e.g., Adeney (2006), p. 658 (stating that the French courts "allow full weight to the author's feelings" but that these feelings are not an element of the claim); Swedish Supreme Court NJA 2008 Sec. 309 (explaining that when assessing whether alternations can be regarded as offensive to the author, the alterations must be viewed from the author's point of view, but against an objective measuring stick); Hansmann and Santilli (1997), p. 102 (discussing how the right of integrity protects most directly the subjective personal anguish the author feels from seeing his/her work abused).

77 See Platt (2010), p. 960 (stating that the pursuant to Art. $6^{\text {bis }}(3)$, the national law of the state in which the author brings the claim shall govern). The phrase in Art. 5(2) and $6^{\text {bis }}(3)$ Berne Convention that protection shall be "governed exclusively by the laws of the country where protection is claimed" is open to several interpretations.

78 The exception in Art. 1(2)(g) Rome II for non-contractual obligations arising out of violations of privacy and rights relating to personality, including defamation should arguably be given a restrictive interpretation that does not go beyond the reason for the exception, which dealt with conflicts between the freedom of expression and the right to privacy.
} 
rules for personality rights infringements apply. The national conflict of law rules for some Member States follow a lex originis approach for copyright including moral rights and apply the law of first publication or the personal law of the author, both of which are likely to correspond with the Member State of the author's centre of interest. ${ }^{79}$ At least one Member State that follows a territorial approach to choice of law for the economic rights conferred by copyright still makes an exception for the ubiquitous infringement of moral rights. In Sweden, professor Strömholm submits that infringements of moral rights should be localised to the country where the author has his/her habitual residence, and that this law should protect the author with respect to infringements taking place everywhere. ${ }^{80}$

If moral rights infringements are characterised as copyright under EU private international law and fall within the scope of Rome II, forum law still applies because the author seeks protection for the forum Member State's territory. ${ }^{81}$ It is then up to forum law as the referenced substantive law to determine whether the infringement of moral rights can be localised within its territory and fall within the scope of its substantive law even with respect to acts which might be localised abroad under other national laws. ${ }^{82}$ EU law has harmonised the commercial aspects of IP law but it has excluded moral rights from these efforts. ${ }^{83}$ Consequently, the Member States' legislation on moral rights diverges, not only in relation to the theoretical basis and content of the rights, but also in their spatial scope of application. ${ }^{84}$

The territorial nature of the Berne Convention is not unanimously accepted, and in any case, the Convention does not localise where an infringement of moral rights takes place. ${ }^{85}$ Consequently, it cannot be excluded that some Member States will

\footnotetext{
79 See e.g. Art. 67 Greek Law No. 2121/1993 on Copyright, Related Rights and Cultural Matters (as last amended by Law No. 3057/2002 (Art. 81) and by Law No. $3207 / 2003$ (Art. 10 para. 33)) and Art. 48 of the Portuguese 1966 Civil Code (establishing that copyright is governed by the law of first publication of the work and if not published, the personal law of the author). These rules cannot be applied to issues within the material scope of application of the Rome II Regulation, which requires a territorial approach with respect to choice of law for the economic rights conferred by copyright. See also van Eechoud (2003), p. 101, fn 281.

80 See Strömholm (2001), pp. 288-290.

81 See Art. 8(1) Rome II.

82 See Fawcett and Torremans (2011), p. 808, fn 55 ("One claims protection under a national law by alleging one has an intellectual property right there that is infringed. The court will then apply that national law to determine whether or not the right has effectively been infringed."); Ulmer (1978), p. 14 (stating that the law under which the plaintiff claims protection determines its own scope of application).

83 See Recital 19 Directive 20017/29/EC of 22 May 2001 on the harmonisation of certain aspects of copyright and related rights in the information society. See also SEC (2004) para 3.5 (concluding that there is no apparent need to harmonise moral rights protection in the Community at this stage); Salokannel et al. (2000) (finding no decisive evidence that the differences in the Member States legislation on moral rights affect the functioning of the internal market).

84 See Adeney (2006), pp. 662-718 (comparing France, Germany, the United Kingdom, and some third countries with respect inter alia the extraterritorial application of the moral rights laws). See generally Platt (2010) (discussing inter alia the differences between the French monist approach and the German dualist approach to copyright); Dworkin (1994) (discussing the common law approach to copyright inter alia in the United Kingdom).
}

85 See Koumantos (1988), pp. 416-418 (maintaining that the Berne Convention is not based on the assumption that copyright law should be applied on a territorial basis to determine the existence and scope 
localise the infringement in the Member State of the author's habitual residence. Indeed, Member States following a droits acquis approach to copyright view moral rights like personality rights, and as such may not be limited to the exploitation of the rights on the territorial market. ${ }^{86}$ For example, the Greek and Portuguese Copyright Acts are not explicitly territorially limited but rely on a choice of law rule to determine the spatial scope of the applicable law. If the author claims protection for the forum Member State, that State's law will apply under Art. 8(1) Rome II, and as stated, the law determines its own spatial scope of application. Similarly, if the author brings the claim in a common law Member State, that State's law will apply under Art. 8(1) Rome II as the country for which protection is claimed. In contrast, however, in the Member States following the common law tradition, the substantive law of moral rights is territorially limited to the acts of infringement in the territory. ${ }^{87}$ In either case, the courts of a Member State that protects authors habitually resident in its territory under forum law are arguably best placed to rule on the damage localised within its territory. ${ }^{88}$

The possibility for a natural person who has created a work to bring a claim for infringement of moral rights before a court in the Member State of his/her centre of interests arguably existed, however, already after the CJEU's judgment in eDate and others. An interesting question is whether the decision in Bolagsupplysningen extends this alternative to right holders who are legal persons. At first, this question seems bizarre because from a European perspective, copyright arises in the natural person who creates a work by imprinting it with his/her personality, and the moral rights conferred by copyright are inalienable. ${ }^{89}$ This leads to the conclusion that only natural persons enjoy moral rights conferred by copyright under European law. ${ }^{90}$ Notwithstanding this, however, some Member States recognise as the author of a collective work the person under whose direction the work was created, and accept the possibility of this person being a legal person, which can enjoy moral rights. ${ }^{91}$ These moral rights would likely be limited to certain moral rights such as

\section{Footnote 85 continued}

(e.g. the rights and their limitations) of a copyright and that it is up to the forum state's choice of law rules to determine the applicable law).

86 See Matulionyte (2012), p. 265; van Eechoud (2003), pp. 99-103.

87 Torremans (2000), p. 103. See also Adeney (2006), pp. 691-692.

88 See Pinckney, para. 45 (stating that "if the protection granted by the Member State of the place of the court seised is applicable only in that Member State, the court seised only has jurisdiction to determine the damage caused within the Member State in which it is situated.") An $e$ contrario interpretation of this statement suggests that if the protection granted by the Member State at the place of the court seised is applicable to damage caused by acts outside the Member State but localized within the territory, the court's jurisdiction would not be limited.

89 Davies and Garnett (2016), p. 1240.

90 Davies and Garnett (2016), pp. 1239-1240 ("It is of course fundamental that the beneficiary of the moral rights is in the first place the "author', i.e. the natural person who has created the work."); Adeney (2006), p. 115 (stating that it was "inconceivable" that the definition of author in the Berne Convention could include legal persons).

91 Davies and Garnett (2016), pp. 1239-1240; Bretonnière (2012) (discussing the French Supreme Court's holding that "the natural or legal person at the initiative of a collective work is vested with the author's rights over this work and, in particular, the moral rights prerogatives"). 
the right of attribution and reputational rights. Indeed, legal persons can hardly claim personality rights that emanate from human dignity such as the right to protection for honour. In that more limited respect, it seems that the CJEU's reasoning in Bolagsupplysningen is applicable to legal persons claiming infringement of moral rights conferred by copyright. ${ }^{92}$

The CJEU's statement in Bolagsupplysningen that economic activity must be carried out mainly in a certain Member State in order to invoke the centre of interests basis of jurisdiction is likely to raise difficult questions with respect to how to draw the line. Indeed, can internationally renowned creators, such as the Swedish video and film director Jonas Åkerlund, who probably earns more money directing US music videos than from jobs at home in Sweden, have his centre of interests in Sweden $?^{93}$ To what extent do the circumstances of the dispute at hand affect the identification of an author's centre of interests? For example, is it relevant when identifying Åkerlund's centre of interests that the work infringed is not well known to a Swedish audience or if the alleged infringer who uploads the infringing content is targeting markets other than Sweden?

If a court in the Member State of origin applies its own law to protect the moral rights of authors habitually resident in its territory with effects in other Member States, this might raise difficulties when the judgment is enforced in another Member State. ${ }^{94}$ As a general rule, a judgment given in one Member State must be enforced in another Member State with only a few limited grounds for refusal. ${ }^{95}$ If the content that the court of origin orders the defendant to remove is legal in the Member State of the enforcing court, the defendant may claim that enforcement should be refused on the ground that it would be manifestly contrary to public policy (ordre public) in the receiving Member State. ${ }^{96}$ For example, assume that a defendant domiciled in Sweden uploads the French film "Le voyage Dans la Lune" (Trip to the moon), the economic rights of which have expired, onto its Swedish homepage, where the defendant makes some satirical changes to the film. Georges Méliès heirs then bring a claim for the infringement of moral rights in France on the

\footnotetext{
92 See Sect. 3.4 for a discussion of whether some claims for the infringement of moral rights could be characterised as unfair competition under an autonomous EU definition, such as when a competitor disparages an author's work.

93 Åkerlund's video for Madonna's song "Ray of Light" won a Grammy Award for Best Music Video at 1998 MTV Video Music Awards. See Wikipedia page on Jonas Åkerlund https://en.wikipedia.org/wiki/ Jonas_Åkerlund. Accessed 29 August 2018.

94 Obstacles to the application of forum law would not arise at the choice of law stage because the rule in the Rome II Regulation on overriding mandatory provisions does not permit the court to apply foreign overriding mandatory provisions of law. See Art. 16 Rome II. Similarly, the exception for the public policy rule protects only the public policy of the forum Member State. See Art. 26 Rome II.

95 Art. 39 BIa. Even if the server on which the defendant stores the infringing content is located in a state outside the EU or Lugano contracting states, a judgment can be enforced against the defendant in its Member State of domicile by fines, contempt of court, or other coercive measures. If the law of the enforcing Member State does not contain a coercive measure similar to that ordered by the court of origin, the objective pursued by that measure must be attained by the competent court of that other Member State by having recourse to the relevant provisions of its national law which are such as to ensure that the prohibition is complied with in an equivalent manner. See judgment of 12 April 2011, DHL Express France (C-235/09, ECR 2011 p. I-2801) ECLI:EU:C:2011:238.
}

96 Art. 45(1)(a) BIa. 
ground that it is the author's centre of interest. The French court applies French law which protects morals rights perpetually and finds that the changes are prejudicial to the author's honour. The French court orders the Swedish defendant to remove the film from its website even though the use of the work is legal in the Sweden.

An argument might be made that an extraterritorial application of French copyright law violates internationally accepted views on the territorial scope of IP rights. ${ }^{97}$ While this argument has clout with respect to patent rights, it is less persuasive with respect to copyright for which a territoriality principle is not unanimously accepted. An additional argument might be that enforcement violates the defendant's constitutional right of freedom of expression. However, the ordre public exception is narrowly applied. ${ }^{98}$ These questions may lead to legal uncertainty for users of copyright material.

\subsection{Complementary Tort Claims}

A right holder may rely on a variety of complementary tort claims under the laws of the Member States in addition to or instead of a claim for the infringement of an IP right. ${ }^{99}$ Examples of such claims are unfair imitation of a sign protected by a trademark, passing off, commercial disparagement, defamation, malicious falsehood, the right to one's name under Art. 12 of the German Civil Code, and protection of general personality rights under German and French case law. Depending on the Member State, such causes of action may have their theoretical basis in unfair competition law or in personality rights. The question whether the centre of interests basis of jurisdiction is available cannot depend, however, on the classification of a claim under national law; the classification must be made pursuant to an autonomous EU definition.

A starting point for an EU definition of acts of unfair competition is Art. $10^{\text {bis }}$ of the Paris Convention, which is binding on all EU Member States. According to paragraph 2 of that provision, "[a]ny act of competition contrary to honest practices in industrial or commercial matters constitutes an act of unfair competition." Paragraph 3 lists three examples that "in particular shall be prohibited" but the examples are not exhaustive. ${ }^{100}$ Moreover, recital 21 of the Rome II Regulation suggests that unfair competition should be given a broad definition for the purpose

\footnotetext{
97 See by analogy Sender (2002), p. 270 (stating that the public policy exception may apply where the law of the protecting country defies the internationally accepted views on the territorial scope of patents rights and claims extraterritorial application).

98 See e.g., NJA 1998 p. 817 (declining to refuse enforcement of a Norwegian court judgment ordering the defendant to pay damages for defamation even though the defendant's statements would be protected under the Swedish rules on freedom of expression).

99 See Fawcett and Torremans (2011), p. 449; Christie (2017), p. 158; Opinion of Advocate General Bobek, Bolagsupplysningen, paras. 55-60; Beverley-Smith et al. (2005), p. 109.

100 See Art. $10^{\text {bis }}$ (3) Paris Convention ("(i) all acts of such a nature as to create confusion by any means whatever with the establishment, the goods, or the industrial or commercial activities, of a competitor; (ii) false allegations in the course of trade of such a nature as to discredit the establishment, the goods, or the industrial or commercial activities, of a competitor; (iii) indications or allegations the use of which in the course of trade is liable to mislead the public as to the nature, the manufacturing process, the characteristics, the suitability for their purpose, or the quantity, of the goods").
} 
of applicable law. ${ }^{101}$ This is arguably true also for jurisdiction. Thus, it is submitted that claims between competing traders or between a trader and an association of consumers concerning industrial or commercial matters should be classified as claims for unfair competition and not violations of personality rights for the purpose of jurisdiction and applicable law. ${ }^{102}$

It is submitted that the centre of interests basis of jurisdiction is generally not applicable to claims of online violations of unfair competition. Pursuant to Art. $10^{\text {bis }}$ Paris Convention, all Member States must ensure effective protection against unfair competition. ${ }^{103}$ In this respect, protection against unfair competition is similar to personality rights in that all Member States must provide protection. The protection conferred under the general EU choice of law rule on unfair competition is similar, however, to the protection conferred by commercial IP law in that the protection is usually limited to a specific territory. ${ }^{104}$ The objective of modern rules against unfair competition is to protect not only competitors (horizontal dimension) but also consumers and the public in general (vertical relations). ${ }^{105}$ The general rule on unfair competition in the Rome II Regulation reflects this triple objective. Indeed, this rule uses as its point of reference the country where competitive relations or the collective interests of consumers are, or are likely to be, affected. ${ }^{106}$ Thus, the applicable substantive law protects competitors, consumers and the public only in the affected market, and if several markets are affected, several laws will be applicable. ${ }^{107}$ In addition, only evidence concerning the impact that the unfair conduct has in the affected Member State is relevant to proving the unfair competition claim under that Member State's law. Consequently, the courts of each Member State where the collective interests of consumers are affected by the allegedly unfair competitive activities are best placed to assess whether such conduct affects the collective interests of consumers within their territories and under their

\footnotetext{
101 Hellner (2007), p. 68 (submitting that recital 21, which speaks of a conflict-of-law rule that "should protect competitors, consumers and the general public and ensure that the market economy functions properly" suggesting that a relatively wide meaning is intended). See also Proposal for a Regulation of the European Parliament and the Council on the law applicable to non-contractual obligations ("ROME II"), COM(2003) 427 final - 2003/0168, Brussels, 22 July 2003 (Rome II Proposal), p. 15 (explaining the broad objectives of the private international law rule on unfair competition in the Rome II Regulation).

102 See Dickinson (2008), p. 240; Hellner (2014), p. 67 (making a similar claim but with respect to applicable law).

103 See Art. $10^{\text {bis }}$ Paris Convention.

104 See Opinion of Advocate General Wathelet delivered on 9 November 2016, Concurrence, paras. 68-71.

105 Rome II Proposal, p. 15; Recital 21 Rome II Regulation (informing that the conflict-of-law rule on unfair competition should protect competitors, consumers and the general public and ensure that the market economy functions properly).

106 See Art. 6(1) Rome II.

107 Hellner (2014), p. 158; Rome II Proposal, p. 16. Pursuant to the Directive on Electronic Commerce, a provider of an electronic commerce service may not be subject to stricter requirements than those provided for by the substantive law applicable in the Member State in which that service provider is established. eDate, para. 68.
} 
national laws. ${ }^{108}$ This result is also consistent with the objective of foreseeability because a trader engaging in unfair competitive conduct can reasonably expect to be sued in the courts of the Member States where its conduct affects the market.

The CJEU has not ruled specifically on the applicability of the centre of interests basis of jurisdiction to unfair competition claims. ${ }^{109}$ It has ruled, however, that for the purpose of jurisdiction over an action for the violation of a prohibition on resale outside a selective distribution network by sales made on foreign websites, the damage occurs in the territory of the Member State which protects against such violations, which is the territory in which the claimant alleges a reduction in its sales. ${ }^{110}$ Similarly, in a non-internet case involving a claim of unfair competition based on the unlawful comparative advertising or unfair imitation of a sign protected by a Community trade mark, the CJEU localised the damage in the Member State in which the protection of the IP right by means of national unfair competition law was at issue. ${ }^{111}$ In both cases, the CJEU localised the damage in the Member State that offered the protection against the unfair competition. ${ }^{12}$

The situation may be different when an act of unfair competition exclusively affects the interests of a specific competitor such as the unlawful use or disclosure of trade secrets over the internet. ${ }^{113}$ While these acts are likely to have indirect effects on all the markets where the competitors operate, the direct damage suffered by the injured trader might be localised where the injured trader has its centre of interests. For example, assume that firm $\mathrm{X}$ established in State A operates in markets A, B, and C. Assume that firm Y, which also operates in markets A, B, and C, unlawfully acquires the plans for firm X's new advertising campaign, which firm Y uses to advertise its own products over the internet. Does the direct damage suffered by firm $\mathrm{X}$ occur in State A where firm X mainly carries out its business or in States A, B, and $\mathrm{C}$ due to those being the States where both firms sell products. ${ }^{114}$

\footnotetext{
108 See Dickinson (2008), pp. 398-399 (remarking that the localisation of damage for the purpose of jurisdiction should preferably correspond to the interpretation of damage for the purpose of choosing the applicable law).

109 A recent CJEU non-internet case in the closely related field of competition law has certain language that is reminiscent of a centre of interest basis of jurisdiction but the case is otherwise consistent with the approach described here, that the damage occurs in the Member State where the market is affected. See flyLAL-Lithuanian Airlines, paras. 39-40.

110 See Concurrence, para. 34.

111 Coty Germany, paras. 55-56.

112 In neither of these cases, however, did the plaintiffs claim that the acts of unfair competition affected markets in several Member States.

113 See Rome II Proposal, p. 16.

114 This reasoning has some support in non-internet competition law case, where the CJEU localised the damage suffered by victims of a cartel who incurred additional costs because of artificially high prices in a number of Member States, at each victim's registered office. The CJEU found that each victim suffered direct damage in the Member States where its registered office was located even though the restrictive acts had effects on the markets in the Member States where each victim bought products covered by the cartel agreement. While the CJEU does not use the terminology centre of interests, the case is analogous to the centre of interests cases because the CJEU localises the damage in the Member State where the restrictive conduct actually manifests itself on the immediate victim, notwithstanding that there are indirect effects on markets. See judgment of 21 May 2015, CDC Hydrogen Peroxide (C-352/13) ECLI:EU:C:2015:335, paras. 52-53.
} 
What suggests the applicability of the centre basis of jurisdiction in these cases is that for the purpose of choice of law, Rome II departs from the connecting factor where the competitive relations or the collective interests of consumers are, or are likely to be, affected in favour of the law of the country where the direct damage occurs (although this law may be displaced if the parties have a common habitual residence or if the tort is manifestly more closely connected with another country). ${ }^{115}$ When an act of unfair competition exclusively affects the interests of a specific competitor, the object of protection is the competitor and not the market as is the case under the general unfair competition rule. ${ }^{116}$ In the example above, the direct damage arguably occurs where firm X developed and stores the trade secret, which likely coincides with the Member State of its centre of interests. ${ }^{117}$ If this is the case, the courts of the Member State where firm X has its centre of interests would arguably be best placed to rule on all the damage. This result is also consistent with the objective of foreseeability because a trader that uses or discloses the trade secret of another trader is usually in the position to know that trader's centre of interest and can reasonably expect to be sued there.

As an exception to the general choice of law rule on unfair competition, the exception should be narrowly interpreted. It is submitted that this exception would not apply to complementary tort claims that could be brought in addition to or instead of a claim for the infringement of an IP right such as a claim for unlawful comparative advertising or unfair imitation of a sign protected by a national or EU trademark. The reason for this is that such claims do not exclusively affect the interests of a specific competitor, but directly affect the competitive relations or the collective interests of consumers. ${ }^{118}$ For these cases, the evidence needed to prove a claim of unfair competition for unlawful acts in relation to subject matter protected by commercial IP rights would be located in each State whose market was affected by the unlawful acts, and the forum court would need to apply these States' laws. In such cases, the application of the centre of interests basis of jurisdiction would not be justified. In addition, localising damage arising from unfair competitive acts in relation to subject matter protected by commercial IP rights in each Member State that protects against these acts under their national unfair competition law, avoids issues concerning the exclusive jurisdiction of the Member State courts over proceedings concerning national IP rights registered in their territories. ${ }^{119}$ The reason for this is that the courts of the Member State having jurisdiction under the

\footnotetext{
115 Art. 6(2) and Art. 4(1-3) Rome II.

116 Hellner (2007), p. 57.

117 This example is based loosely on the example concerning choice of law given in Hellner (2007), p. 57, which is based on the example in the Rome II Proposal, p. 16.

118 Examples given by the Commission in its Rome II Proposal of acts of unfair competition that exclusively affect the interests of a specific competitor are enticing away a competitor's staff, corruption, industrial espionage, disclosure of business secrets or inducing breach of contract. Rome II Proposal, p. 16.

119 See GAT (holding that the rule on exclusive jurisdiction applies to "all proceedings relating to the registration or validity of a patent, irrespective of whether the issue is raised by way of an action or a plea in objection.").
} 
damage head of Art. 7(2) BIa will be the courts having jurisdiction under Art. 24(4) BIa. $^{120}$

\section{Jurisdiction over Actions for Injunctions in Transborder Intellectual Property Disputes at the Place of Damage}

The question raised here is what the decision in Bolagsupplysningen means for the possibility for a right holder to obtain an injunction in the Member State of registration and/or protection to end an infringement in the forum state. It is submitted that the decision does not mean anything new but only clarifies what should have been obvious all along. That is, the scope of a Member State court's jurisdiction to issue an injunction mirrors the scope of that court's jurisdiction over the dispute.

A Member State court exercising jurisdiction based on damage occurring in its own territory has jurisdiction only with respect to damage in its territory and may issue injunctions only with respect to that damage. This is true for both a Member State court at the victim's centre of interests and in every Member State where content is accessible where the victim claims a reputation. The difference is that the CJEU localises damage occurring from personality rights infringements on the internet in the Member State of the victim's centre of interests. Thus, the Member State courts there have jurisdiction to issue an injunction for rectification and removal of the content with effect everywhere because even if the content is accessible in all the Member States, its impact is felt (and localised) at the victim's centre of interests.

In contrast, a Member State court exercising jurisdiction based on the accessibility of the illegal content in its territory has jurisdiction to issue injunctions only with respect to its own territory. If it would grant an injunction for rectification and removal of the content with effect everywhere, it would be exercising jurisdiction over the territories of the other Member States in light of the fact that such an injunction affects the accessibility of the content in the other Member States over whose territories the adjudicating court does not have jurisdiction.

The CJEU states this quite succinctly when it pronounces:

However, in the light of the ubiquitous nature of the information and content placed online on a website and the fact that the scope of their distribution is, in principle, universal, an application for the rectification of the former and the removal of the latter is a single and indivisible application and can, consequently, only be made before a court with jurisdiction to rule on the entirety of an application for compensation for damage, and not before a court that does not have jurisdiction to do so. ${ }^{121}$

\footnotetext{
120 This would not be the case, however, if the unlawful acts were in relation to an EU trademark or a Community Design unless the right holder also brings proceedings for the infringement of the EU trademark or Community Design right. See Art. 124(d) Regulation (EU) 2017/1001 of the European Parliament and of the Council of 14 June 2017 on the European trade mark; Art. 81(d) Council Regulation (EC) No 6/2002 of 12 December 2001 on Community Designs.

121 Bolagsupplysningen, para. 48 (internal citations removed).
} 
Thus, it is submitted that any Member State court that had previously granted an injunction ordering the removal of defamatory content published on the internet when exercising jurisdiction based on the accessibility of the content in their jurisdiction, exceeded the scope of their jurisdiction. ${ }^{122}$

This holds true also with respect to infringements of IP rights on the internet. That is, a court in a Member State where a trademark is registered does not have jurisdiction to order a defendant to cease using the trademark on the internet with effect for all Member States because the court would exceed the scope of its jurisdiction, which is limited to its territory. ${ }^{123}$ Today, geoblocking technologies are quite sophisticated for ensuring that infringing effects are not felt within a certain country's territory. ${ }^{124}$ In addition, a creative court can tailor an injunction with other solutions such as disclaimers and gateway pages to delineate their activities to certain Member States. ${ }^{125}$ While the CJEU may be criticised for not considering geoblocking technology, ${ }^{126}$ the issue of an injunction for a specific Member State was not raised in Bolagsupplysningen because the plaintiff had sought an injunction for rectification and removal of the content from the internet with effect everywhere. It is submitted therefore that Bolagsupplysningen does not prevent a Member State court from ordering the defendant to cease the infringement in the territory. ${ }^{127}$

\section{Conclusions}

The article concludes that the centre of interests basis of jurisdiction, confirmed and extended to legal persons in Bolagsupplysningen, is generally not applicable to right holders claiming infringements of IP rights and/or complementary tort claims. The reason for this is that these claims are territorial in nature in that protection is granted for the specific territories of the Member States under those Member States' laws. Two exceptions to this general conclusion may be infringements of moral rights and unfair competition claims where the act exclusively affects the interests of a specific competitor. That said, many questions remain with respect to the localisation of a victim's centre of interests. First, how do the national courts draw

\footnotetext{
122 See Lutzi (2017), p. 692 (reporting that the German courts had been willing to grant such injunctions even though their jurisdiction was based on the occurrence of damage in Germany).

123 See by analogy Art. 13 WIPO, Joint Recommendation (Publication 845) concerning provisions on the protection of marks and other industrial property rights in signs, on the Internet, 2001 and accompanying notes (explaining that Injunctions should generally be limited to what is necessary to prevent or remove the commercial effect in the Member State in which the infringed right is protected).

124 Peukert (2016), pp. 72-73; Trimble (2015), pp. 400-401.

125 See Kur (2005), p. 178.

126 See Bogdan (2017-2018), p. 677.

127 Geoblocking does not violate the EU's new Geoblocking Regulation when blocking is necessary to ensure compliance the laws of a Member State in accordance with Union law, to which the trader's activities are subject. See Art. 3(3) Regulation (EU) 2018/302 of the European Parliament and of the Council of 28 February 2018 on addressing unjustified geo-blocking and other forms of discrimination based on customers' nationality, place of residence or place of establishment within the internal market and amending Regulations (EC) No 2006/2004 and (EU) 2017/2394 and Directive 2009/22/EC (Text with EEA relevance).
} 
the line when determining whether a victim carries out economic activities mainly in a certain Member State? Second, to what extent do the circumstances of the actual dispute affect the localisation of the centre of interests? The CJEU will need to answer these questions in future cases.

In addition, the article concludes that the judgment in Bolagsupplysningen does not affect a right holder's ability to obtain an injunction in the Member State in which content accessible on the internet infringes a forum IP right. The court of the Member State of registration and/or protection continues to have jurisdiction to issue injunctions ordering the defendant to terminate the infringing effects in its own territory. It is now beyond doubt that such injunctions may not have the effect of eliminating access to the content in the other Member States.

Still, the centre of interests basis of jurisdiction has the potential to give right holders a great advantage for claims of online infringements of moral rights and acts of unfair competition that exclusively affect them, as it allows them to obtain relief without territorial restrictions. It can be expected that authors and traders will take advantage of this opportunity when considering their IP litigation strategies. Indeed, authors and traders may haul alleged infringers domiciled in other Member States before the courts of their home Member States and obtain an injunction for rectification and removal of the content with effect everywhere (and damages). Moreover, it is possible that the claim in its entirety will be subject to forum law. This allows an author or trader with a centre of interests in a Member State granting strong protection to export this law to the other Member States. A possible consequence is that content may be removed from the internet even though its use is legal in other Member States. This may lead to more challenges to the enforcement of judgments on public policy grounds. A serious question can be raised whether these legal uncertainties harm the proper functioning of the Internal Market.

Acknowledgements The author would like to thank Prof., Jur. Dr., Fil. Dr h.c. Marianne Levin, Stockholm University and Prof. Dr. Annette Kur, Max Planck Institute for Innovation and Competition for their valuable input to an earlier version of this article.

Open Access This article is distributed under the terms of the Creative Commons Attribution 4.0 International License (http://creativecommons.org/licenses/by/4.0/), which permits unrestricted use, distribution, and reproduction in any medium, provided you give appropriate credit to the original author(s) and the source, provide a link to the Creative Commons license, and indicate if changes were made.

\section{References}

Adeney E (2006) The moral rights of authors and performers: an international and comparative analysis. Oxford University Press, Oxford

Beverley-Smith H et al (2005) Privacy, property and personality: civil law perspectives on commercial appropriation. Cambridge University Press, Cambridge

Bogdan M (2013) Jurisdiction in disputes about infringements of intellectual property rights on the internet in view of recent ECJ case law. Masaryk Univ J Law Technol 7:193-200

Bogdan M (2017-18) Domsrätt över personlighetskränkningar på internet. Juridisk Tidskrift. 29:673-678 
Bretonnière J-F (2012) International report-moral rights in collective works: Supreme Court takes economic view. Baker McKenzie, France. http://www.iam-media.com/reports/detail.aspx?g= 78b26f25-cdc9-4ebe-b448-d91318c45672. Accessed 10 July 2018

Chalmers D et al (2014) European Union law. Cambridge University Press, Cambridge

Christie AF (2017) Private international law principles for ubiquitous intellectual property infringement: a solution in search of a problem? J Private Int Law 13(1):152-183

Davies G, Garnett QCK (2016) Moral rights. Sweet \& Maxwell, London

Dickinson A (2008) The Rome II Regulation: the law applicable to non-contractual obligations. Oxford University Press, Oxford

Dworkin G (1994) The moral right of the author: moral rights and the common law countries. Colum VLA J L Arts 19:229-267

European Commission (2004) Staff Working Paper on the review of the EC legal framework in the field of copyright and related rights, SEC (2004) 995

European Commission (2009) Comparative study on the situation in the 27 Member States as regards the law applicable to non-contractual obligations arising out of violations of privacy and rights relating to personality. JLS/2007/C4/028. Final Report

Fawcett J, Torremans P (2011) Intellectual property and private international law. Oxford University Press, Oxford

Hansmann H, Santilli M (1997) Authors' and artists' moral rights: a comparative legal and economic analysis. Journal of Legal Studies 26:95-143

Hellner M (2007) Unfair competition and acts restricting free competition: a commentary on article 6 of the Rome II Regulation. Yearbook of Private International Law 9:49-69

Hellner M (2014) Rom II-Förordningen: tillämplig lag för utomobligatoriska förpliktelser. Nordstedts Juridik, Stockholm

Koumantos G (1988) Private international law and the Berne Convention. Copyright 24:415

Kur A (2000) The WIPO recommendation for the protection of well-known marks. IIC 37(7/8):824-845

Kur A (2005) Trademark conflicts on the internet: territoriality redefined? In: Basedow J et al (eds) Intellectual property in the conflict of laws. Max-Planck-Institut für ausländisches und internationales privatrecht Tübingen, Mohr Siebeck

Lutzi T (2017) Internet cases in private international law: developing a coherent approach. ICLQ 66(3):687-721

Lutzi T (2018) Shevill is dead, long live Shevill! Law Q Rev 134:208-213

Matulionyte R (2012) IP and applicable law in recent international proposals: report for the International Law Association. J Intell Prop Inf Technol Electron Commerce Law 3:263-305

Maunsbach U (2012) Copyright in a borderless online horizon - comments from a Swedish horizon. In: Axhamn J (ed) Copyright in a borderless online environment. Nordstedts juridik, Stockholm

Pertegás Sender M (2002) Cross-border enforcement of patent rights: analysis of the interface between intellectual property and private international law. Oxford University Press, Oxford

Peukert A (2016) The coexistence of trade marks laws and rights on the Internet, and the impact of geolocation technologies. IIC 47(1):60-86

Platt R (2010) A comparative survey of moral rights. J Copyright Soc USA 57:951-986

Rättzén M (2017) Den territoriella begränsningen och domsrätt för immaterialrättsliga intrång. Nordiskt Immateriellt Rättsskydd 4:317-349

Salokannel M et al. (2000) Study contract concerning moral rights in the context of the exploitation of works through digital technology. No ETD/99/B5-3000/E 28 April 2000

Schack H (2009) The law applicable to unregistered IP rights after Rome II. Ritsumeikan L Rev 26:129-144

Stone P (2013) Territorial targeting in EU private law. Inf Commun Technol Law 22:14-26

Strömholm S (2001) Upphovsrätt och internationell privaträtt. Nordstedts Juridik, Stockholm

Svantesson D (2016) Private international law and the internet. Wolters Kluwer, Alphen aan den Rijn

Torremans P (2000) Moral rights in the digital age. In: Stamatoudi I, Torremans P (eds) Copyright in the new digital environment. Sweet \& Maxwell, London

Trimble M (2015) The multiplicity of copyright laws on the Internet. Fordham Intell Prop Media Ent L J 25:339-406

Ulmer E (1978) Intellectual property rights and the conflict of laws. Kluwer, Law and Taxation Publishing Division, Alphen aan den Rijn

van Eechoud M (2003) Choice of law in copyright and related rights: alternatives to the lex protectionis. Kluwer Law International, Alphen aan den Rijn 
Von Bomhard V, Geier A (2017) Unregistered trademarks in EU trademark law. Trademark Rep 107(3):677-700

Xalabarder R (2015) Jurisdiction and applicable law issues for the protection of moral rights on-line. In: Brison $\mathrm{F}$ et al. (eds), Moral rights in the 21st century: the changing role of the moral rights in an area of information overload. Contributions of the Congress 17-20 September 2014 of the Association littéraire et artistique internationale (ALAI), Larcier

Zingales N (2017) The legal framework for SEP disputes in EU post-Huawei: whiter harmonization?. ISSN 1572-4042, TILEC Discussion paper. https://papers.ssrn.com/sol3/papers.cfm?abstract_id= 3017102. Accessed 11 July 2018 